\title{
Transcriptome analysis of diploid and triploid Populus tomentosa
}

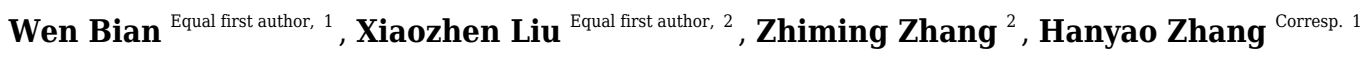 \\ ${ }^{1}$ Key Laboratory for Forest Resources Conservation and Utilization in the Southwest Mountains of China, Ministry of Education, Southwest Forestry \\ University, Kunming, Yunnan, China \\ ${ }^{2}$ Key Laboratory of Biodiversity Conservation in Southwest China, State Forest Administration, Southwest Forestry University, Kunming, Yunnan, China \\ Corresponding Author: Hanyao Zhang \\ Email address: zhanghanyao@swfu.edu.cn
}

Triploid Chinese white poplar (Populus tomentosa Carr., Salicaceae) has stronger advantages in growth and better stress resistance and wood quality than diploid $P$. tomentosa. Using transcriptome sequencing technology to identify candidate transcriptome-based markers for growth vigor in young tree tissue is of great significance for the breeding of $P$. tomentosa varieties in the future. In this study, the cuttings of diploid and triploid $P$. tomentosa were used as plant materials, transcriptome sequencing was carried out, and their tissue culture materials were used for RT-qPCR verification of the expression of genes. The results showed that 12,240 differentially expressed genes in diploid and triploid $P$. tomentosa transcripts were annotated and enriched into 135 metabolic pathways. The top six pathways that enriched the most significantly different genes were plant-pathogen interaction, phenylpropanoid biosynthesis, MAPK signalling pathway-plant, ascorbate and aldarate metabolism, diterpenoid biosynthesis, and betalain biosynthesis pathway. Ten growth-related genes were selected from pathways of plant hormone signal transduction and carbon fixation in photosynthetic organisms for RT-qPCR verification. The expression levels of $M D H$ and $C Y C D 3$ in tissue-cultured and greenhouse planted triploid $P$. tomentosa were higher than those in tissue-cultured diploid $P$. tomentosa, which was consist ent with the TMM values calculated by transcriptome. 
2

3

4

5 of Education, Southwest Forestry University, Kunming Yunnan, China;

$6{ }^{2}$ Key Laboratory of Biodiversity Conservation in Southwest China, State Forest Administration, Southwest Forestry

7 University, Kunming, Yunnan, China.

8

9 \#equal first author.

$10 *$ Corresponding author:

11

12

13

14

Wen Bian ${ }^{1, \#}$, Xiaozhen Liu ${ }^{2, \#}$, Zhiming Zhang ${ }^{2}$, Hanyao Zhang ${ }^{1, *}$

\section{Professor Hanyao Zhang, PhD}

Key Laboratory for Forest Resources Conservation and Utilization in the Southwest Mountains of China, Ministry of Education, Southwest Forestry University, 300\# Bailongsi, Kunming Yunnan 650224, China

Email address: zhanghanyao@hotmail.com

Phone number: (+86 87163863575$)$

Fax number: (+86 87163863022$)$

\section{Abstract}

Triploid Chinese white poplar (Populus tomentosa Carr., Salicaceae) has stronger advantages in growth and better stress resistance and wood quality than diploid $P$. tomentosa. Using transcriptome sequencing technology to identify candidate transcriptome-based markers for growth vigor in young tree tissue is of great significance for the breeding of $P$. tomentosa varieties in the future. In this study, the cuttings of diploid and triploid $P$. tomentosa were used as plant materials, transcriptome sequencing was carried out, and their tissue culture materials were used for RT-qPCR verification of the expression of genes. The results showed that 12,240 differentially expressed genes in diploid and triploid $P$. tomentosa transcripts were annotated and enriched into

\section{Transcriptome analysis of diploid and triploid Populus tomentosa}


135 metabolic pathways. The top six pathways that enriched the most significantly different genes were plantpathogen interaction, phenylpropanoid biosynthesis, MAPK signalling pathway-plant, ascorbate and aldarate metabolism, diterpenoid biosynthesis, and betalain biosynthesis pathway. Ten growth-related genes were selected from pathways of plant hormone signal transduction and carbon fixation in photosynthetic organisms for RT-qPCR verification. The expression levels of $M D H$ and $C Y C D 3$ in tissue-cultured and greenhouse planted triploid $P$. tomentosa were higher than those in tissue-cultured diploid P. tomentosa, which was consistent with the TMM values calculated by transcriptome.

Key words: Populus tomentosa; transcriptome analysis; GO categories; KEGG categories; RT-qPCR analysis.

\section{Introduction}

Populus tomentosa is an important timber and ecological tree species in northern China, and it is one of the most important fast-growing native tree species in farmland shelterbelt, timber forest, and landscape tree from North China to Northwest China (Fan et al., 2005; Li et al., 2019a). In terms of wood, it has good wood quality (with long fiber and white wood), high-fiber content, good paint, and cementation properties. In terms of growth characteristics, it has fast growth, long life (compared to other trees in northern China), drought and salinity resistance, strong smoke and pollution resistance, and a crown shape (Ci et al., 2019). Based on its excellent characteristics and the needs of ecological and economic construction, researchers have paid more and more attention to the field of forest breeding in China (Zong et al., 2019).

At present, due to the problems of high genetic heterozygosity and the long breeding cycle of forest trees, the genetic improvement process of conventional cross-breeding is seriously hindered, and the productivity of varieties used in forestry production is difficult to meet the needs of industrial development for wood, biomass, paper, fuel and biomaterials (Harfouche et al., 2012; Zong et al., 2019). An in-depth study of the biological basis of wood formation and analysis of the genetic regulation mechanism of wood formations was essential to accelerate the process of improved forest varieties (Lin et al., 2017). The study of tree transcriptomes enables us to analyze the genetic basis of the formation of tree traits (Hao et al., 2011; Zhang et al., 2019; Sun et al., 2019). Because of long cycles, breeding of new varieties with expected traits cannot be rapidly achieved through traditional crossing methods alone (Harfouche et al., 2012). The combination of conventional breeding and 
52 modern breeding techniques represented by genomics is the main trend in the field of forest breeding in the 53 future (Harfouche et al., 2012). Combining conventional breeding methods with transcriptome sequencing 54 technology to screen tree growth-related genes is not only a breakthrough in variety selection but also a new 55 field of exploration, and to identify candidate transcriptome-based markers for growth vigor in young tree tissue 56 is very important (Hao et al., 2011; Sun et al., 2019).

Polyploidy is important for the evolution of plants (Sattler et al., 2016; Liu and Sun, 2019). RNA interference and dosage compensation in a polyploid cell often leads to epigenetic changes as it alters the gene expression levels (Osborn et al., 2003; Soltis et al., 2004). Many studies have found significant differences between the expression levels of genes in diploid and polyploid plants (Osborn et al., 2003; Gutierrez-Gonzalez and Garvin, 2017; Li et al., 2019b). Polyploid plants often exhibit commercially beneficial qualities, e.g. increased vigour, improved product quality, enlarged organs, enhanced tolerance to both biotic and abiotic stresses and increased heterozygosity and heterosis, in contrast to their diploid relatives (Sattler et al., 2016; Liu and Sun, 2019). Polyploidy often results in downregulated fertility because the expression of fertility-related genes is lower than that of compared to their diploid relatives (Li et al., 2019b). Developing polyploidy in plants has been the focus of many plant breeders for some time (Huang et al., 1990; Bancroft et al., 2011; Rambani et al., 2014; Li et al., 2019b; Shenton et al., 2020).

There are many advantages of triploid P. tomentosa plants compared with diploid ones (Zhu et al., 1995; Chen et al., 2017). Studies have shown that triploid $P$. tomentosa is superior to diploid $P$. tomentosa in both volumes per plant and papermaking (Chen et al., 2017; Li and Zhang, 2000). P. tomentosa has a great advantage in the construction of shelterbelt and fast-growing and high-yield forest (Li et al., 2019a). However, the related studies on the differences in growth between diploid and triploid $P$. tomentosa are mostly focused on phenotypic studies, while there are few studies on the genes that control the differences in their growth characteristics. In this study, the transcriptome analysis was subjected to an analysis of the differences in gene expression between diploid and triploid $P$. tomentosa, which derived from genome doubling and hybridization with different genotypes (Zhang et al., 2008), and RT-qPCR analysis was used for verification of the results of the transcriptome analysis. It would lay a foundation to screen growth-related genes for providing high-quality, fastgrowing industrial timber and speeding up the genetic improvement of forest trees. 
79

80

81

82

83

84

85

86

87

88

89

90

91

92

93

94

95

96

97

98

99

100

101

102

103

\section{Materials and Methods}

\subsection{Materials}

Diploid and triploid P. tomentosa root sprouts were collected in Kunming World Horticultural Expo Park and on the campus of Southwest Forestry University in May 2019. These sites were adjacent to each other. The triploid poplar $[(P$. tomentos $a \times P$. bolleana $) \times$ P. tomentosa $]$ was produced from Beijing Forestry University (Zhang et al., 2008), whereas the diploid plants were native to the area. To obtain samples of the same physiological age, about one-year-old (variability in their ages about one month) well-grown root sprouts were selected and sampled at 9 a.m. The leaves were removed, and about one gram of stem segments under the fifth leaf down from the tip of the branch was sent to Wuhan Huada Gene Company for transcriptome sequencing (Ye et al., 2020). Among them, diploid P. tomentosa stem segments were used as the control group (D1, D2, D3), and triploid P. tomentosa stem segments were considered as the treatment group (T1, T2, T3). D1, D2, D3, T1, T2 and T3 were used to represent biological replicates.

\subsection{Sequencing data filtering}

RNA was extracted using the Tiangen kit (TIANGEN Biotech Beijing Co., Ltd.), which was produced by the Wuhan Huada Gene Company. The library was generated according to the operation manual of the NEBNext ${ }^{\circledR}$ Ultra $^{\mathrm{TM}}$ RNA Library Prep Kit for Illumina ${ }^{\circledR}$ (NEB, USA). The samples were sequenced using the Bgiseq-500 platform. The data were paired-end, and fastq formatted files were used at the beginning of the analysis. The data was filtered using Trimmomatic v0.36 software (Bolger et al., 2014), and Soapnuke v1.4.0 (Chen et al., 2018) was used for statistics. A trimming of the polyA tails was conducted, and a cut-off threshold of Q-score 30 was chosen and bases with Q-score less than 30 were trimmed.

\subsection{Gene annotation}

After obtaining clean reads, Bowtie2 v2.2.5 (http://bowtie-bio.sourceforge.net/Bowtie2/ index.shtml) was used to compare clean reads to P. trichocarpa reference genome (Tuskan et al., 2006) (ftp://plantgenie.org/Data/ PopGenIE/). Then RSEM was used to calculate the expression levels of genes and transcripts (Li and Dewey, 2011). Seven major functional database annotations - KEGG Ortholog, KO; Gene Ontology, GO; NCBI 
104

105

106

107

108

109

110

111

112

113

114

115

116

117

118

119

120

121

122

nonredundant protein sequences, NR; NCBI nucleotide sequences, NT; A manually annotated and reviewed protein sequence database, SwissProt; Protein family, PFAM; and Clusters of Orthologous Groups of proteins, KOG - were performed on the assembled UniGenes. BLAST was used for the functional annotation of NT, Diamond was used for NR, KOG, SwissProt and KEGG, Hmmscan for PFAM and Blast2GO for GO, with the e-value of 1e-10 (Feng et al., 2019).

\subsection{Detection of differentially expressed genes (DEGs)}

Using the transcriptome data of D1, D2, D3, T1, T2 and T3, DESeq2 software (Anders and Huber, 2010) was employed to screen DEGs with parameters of Fold Change $\geqq 2$ and adjusted P-value $\leq 0.001$. The genes with a fold of more than twice in triploid P. tomentosa compared to diploid P. tomentosa and Q-value $\leq 0.001$ were screened as differentially expressed genes. QUANT (https://www.quantsoftware.com/) was used to normalise and reduce the variance and help detect DEGs. The transcripts were filtered to show the minimum count before assessing the differential expression. TMM values were calculated by using the edgeR software (Maza, 2016).

\subsection{Analysis of gene ontology (GO) function and KEGG function of DEGs}

GO annotations were performed using nucleotide data. According to the GO annotation and KEGG annotation results, as well as the functional annotation, the differential genes were functionally classified. The detection of transcription factor families was based on these annotations. Meanwhile, the phyper function (Evans et al., 2000) in R software was used for enrichment analysis, the p-values were calculated and then corrected by False Discovery Rate (FDR) (Burger, 2018). Finally, the function with Q-value $\leq 0.05$ was deemed significant enrichment. The test conducted was one tailed for enrichment.

GetORF was used to detect the ORF of UniGene, while HMMER 3.0 hmmsearch was used to compare the ORF. The characteristics of the transcription factor family were then analysed by PlantTFDB (Sanseverino et al., 2010). The gene alignments were annotated into the plant-disease resistance gene database (PRGdb) by using DIAMOND (https://github.com/bbuchfink/diamond) v0.8.31 software (Buchfink et al., 2015).

The candidate coding region in UniGenes was identified by TransDecoder v2.0.1 software, and then the PFAM protein homologous sequence was examined by BLAST alignment SwissProt database and Hmmscan 
129

130

3.0 ( http://hmmer.org), thus predicting the coding region CDSs. MISA (http://pgrc.ipk-gatersleben.de/misa) was used to detect simple sequence repeats (SSR) in UniGene with the parameters set as default (Sen et al., 2018).

\subsection{Tissue culture of diploid and triploid P. tomentosa}

The leaves of diploid and triploid $P$. tomentosa were inoculated on a callus induction medium (MS+1.2 $\mathrm{mg} / 1$ 6-BA+0.6 mg/l NAA) for 15 days. After which, they were transferred to an aseptic differentiation medium (MS+1.0 mg/1 6-BA+0.4 mg/l NAA) for 28 days. Once the adventitious buds had grown by 2 to $3 \mathrm{~cm}$, they were moved to a rooting medium $(1 / 2 \mathrm{MS}+0.4 \mathrm{mg} / \mathrm{L}$ IBA). After the adventitious roots had grown by 2 to $3 \mathrm{~cm}$, the seedlings were then moved to a greenhouse.

\subsection{Real-time quantitative polymerase chain reaction (RT-qPCR) validation}

To verify the reliability of transcriptome sequencing results and the expression of key genes, diploid and triploid Chinese white poplar tissue culture seedlings of the same age and growth conditions, which were derived from the same trees used for transcriptome, tissue culture plants and planted in the greenhouse, at 1 month, 4 months, 7 months, 10 months and 13 months old plants, were used for RT-qPCR validation. As in transcriptome sequencing, stem segments under the fifth leaf down from the tip of a branch were selected for validation. The method of tissue culture was carried out according to the method reported by Hu et al. (2005). The stem cuttings were sampled at 9 o'clock in the morning.

Ten growth-related genes were selected from the pathway of plant hormone signal transduction (Ko04075), carbon fixation in photosynthetic organisms (Ko00710), nitrogen metabolism (Ko00910) and tryptophan metabolism (Ko00380) for RT-qPCR validation. These genes were up-regulated in triploid $P$. tomentosa compared to diploid P. tomentosa, and taken as candidate markers for plant breeders in the future. Using the EFla as an internal reference gene, and using the gene sequences of the transcriptome, the primers were designed using Primer primer 5 (Lalitha 2000), as listed in Table 1. The RT-qPCR processes were described according to Li et al. (2019b) on a Bio-Rad CFX96TM Real-time PCR Detection System (Bio-Rad, California, USA), with a final volume of $25.0 \mu \mathrm{l}$, containing 2.5 units of Taq DNA polymerase, $0.4 \mathrm{mM}$ deoxyribonucleotides (dNTPs), $20 \mu \mathrm{l}$ of $\mathrm{ddH}_{2} \mathrm{O}, 1 \mu \mathrm{l}$ of cDNA, and $500 \mathrm{nM}$ of each primer. Each sample was carried out in triplicate for the RTqPCR reactions. The data were normalised with the housekeeping gene EF1 $\alpha$, and the method was employed in 
155 line with the previous study (Liu et al., 2018).

\section{Results and Analysis}

157 3.1 Unigene function annotations

158 The length distribution of unigenes is shown in Figure 1. The unigenes were annotated with seven major 159 functional database annotations (KEGG, GO, NR, NT, SwissProt, Pfam, and KOG). Finally there were 6,554 160 (NR: 86.43\%), 71,647 (NT: 93.04\%), 50,143 (SwissProt: 65.12\%), 51,971 (KOG: 67.49\%), 52,404 (KEGG: 161 68.05\%), 50,210 (GO: 65.20\%), and 50,881 (Pfam: 66.07\%) unigenes with access to functional annotations. A 162 total of 55,479 Coding DNA Sequences (CDSs) were detected. At the same time, 21,163 SSRs were detected 163 distributed in 16,304 unigenes, and 3,443 unigene encoding transcription factors were predicted.

It could be seen that the annotations obtained in NT (NBCI nucleic acid sequence database) were the most, 93.04\%; the overall annotation rate was 93.81\%; and the lowest was $65.12 \%$ in the Swissprot database. A total of $86.43 \%$ of the annotations were obtained in the NR (NCBI protein database). According to the specific species distribution chart of the annotations, a total of five species were matched. The highest of the first three were P. trichocarpa, with $53.95 \%$ of the annotations, followed by P. euphratica, with $35.68 \%$ of the annotations, and finally, P. tomentosa, with $3.26 \%$ annotation.

\subsection{Transcription factor (TF) prediction}

The $T F$ prediction results showed that the genes belonged to a total of 55 transcription factor families, of which, with the largest number of genes, was the $M Y B$ gene family, with a total of 438 genes involved in the expression, followed by the $A P 2-E R E B P$ gene family with 290 genes, and finally the $b H L H$ gene family with 239 genes (see Figure 2). Among these transcription factor families, both the $M Y B$ family and the $W R K Y$ family (including 208 genes) are involved in plant growth and development processes, which can provide relevant information for our subsequent screening of growth-related genes.

\subsection{Cluster analysis and GO classification of DEGs}

The number of up-regulated genes in diploid P. tomentos a compared with triploid P. tomentosa was 15,690 and 
179

180

181

182

the down-regulated gene was 16,971 . The scatter plot of DEGs showed that the difference of transcriptional profiles between triploid and diploid samples was obvious (see Figure 3). The GO function was divided into three branches: molecular function, cellular component, and biological process. Figure 4 shows the functional classification based on differential gene detection.

A total of 22,375 differentially expressed genes that had GO annotations were obtained in GO classification entries by using the classification of 32,661 common differential genes. There were 13,720 DEGs in biological processes, including 6,481 up-regulated genes and 6,879 down-regulated genes; 15,963 DEGs in cell composition, including 7,687 up-regulated genes and 8,276 down-regulated genes; and 1,092 DEGs in molecular function, including 8,553 up-regulated genes and 9,539 down-regulated genes.

Among the three branches of GO function entries, the number of DEGs of binding was the largest in molecular function, the number of DEGs of the cell and cell part was the largest in the cellular component, and the number of DEGs of the cellular process was the largest in the biological process. There are 44 DEGs that belonged to lignin production-related transcripts (see Table 2), which are important for tree breeders.

A total of 38 entries were enriched in GO function $(\mathrm{Q} \leq 0.05)$ (see Table 3). Biological processes accounted for $36.8 \%$ of the total, of which catalytic activity accounted for the largest proportion of biological processes, at $42.86 \%$; cell components accounted for $18.5 \%$ of the total, of which cell accounted for $42.85 \%$; and molecular functions accounted for $44.7 \%$ of the total, of which catalytic activity accounted for $47.05 \%$.

\subsection{Analysis of pathway function of DEGs}

Using Q-value $\leq 0.05$ as the standard, 32,661 differential genes were separately analysed by pathway enrichment using the KEGG database. There were 16 significantly enriched KEGG metabolic pathways. Among them, the most frequently occupied pathways were the metabolism branch, with 13, and a total of 19,469 DEGs involved; the second was the biological system branch, with two, and a total of 1,447 DEGs involved; and finally, the environmental information process branch, with one, with 868 DEGs involved.

The results showed that there were 12,240 significantly different genes annotated in the KEGG pathways of diploid and triploid samples. The top differentially expressed genes significantly enriched six pathways were 
204

205

206

207

208

209

210

211

212

213

214

215

216

217

218

219

220

221

222

223

224

225

226

227

228

229

as follows: 1,115 differential gene expression in the plant-pathogen interaction (KO: ko04626) pathway; 396 differential genes in the phenylpropane biosynthesis (KO: ko00940) pathway; 868 differential genes in the mitogen-activated protein kinase (MAPK) plant signalling pathway (KO: ko04016); 170 differential genes expression in the ascorbate and aldarate metabolism pathway (KO: ko00053); 64 differential genes in the diterpenoid biosynthesis pathway (KO: ko00904); and 43 differential genes in the beets red pigment biosynthesis pathway (KO: ko00965). All differentially expressed genes significantly enriched pathways were shown in Table 4. The results showed that there were 496 DEGs upregulated and 619 downregulated in the plant-pathogen interaction pathway, and that there were 864 DEGs enriched in the organismal systems category of GO annotations, 217 DEGs in environmental information processing, 25 DEGs in genetic information processing and nine DEGs in metabolism.

The differential genes in the plant-pathogen interaction (KO: ko04626) pathway could be enriched in 46 GO function entries. These GO function entries are integral components to fungus and ribosome biogenesis in the following components: the membrane, signal transduction, defence response, DNA-templated transcription, calcium ion binding, ADP binding, regulation of membrane potential, cell surface receptor signalling pathway, abscisic acid-activated signalling pathway, protein phosphorylation, peptidyl-serine phosphorylation, lipid metabolic process, intracellular signal transduction, proteolysis, protein autophosphorylation, ATP binding, plasma membrane, mRNA transcription, protein folding, 2-alkenal reductase [NAD(P)] activity, activation of protein kinase activity, kinase activity, regulation of mitotic cell cycle, calcium ion homeostasis, signal transduction by protein phosphorylation, intracellular, response to stress, membrane, extracellular region, metal ion transport, primary miRNA processing, stress-activated protein kinase signalling cascade, cellular transition metal ion homeostasis, response to temperature stimulus, calmodulin-dependent protein kinase activity, mitochondrion, endosome, protein kinase activity, developmental process involved in reproduction, DNAtemplated regulation of transcription, plant-type hypersensitive response, defence response to bacterium, incompatible interaction, lipid catabolic process, pre-miRNA processing and defence response. Among them, the top five entries were 184 differential genes in the integral component of membrane, 174 in the signal transduction, 145 in defence response, 128 in DNA-templated transcription and 53 in calcium ion binding. In 
230

231

233

234

235

236

addition, there were 104 differential genes in the plant-pathogen interaction pathway that had zero expression in the triploid poplar.

In the process of analysing the growth-related pathways, it was found that the growth-related genes were up-regulated and down-regulated, so it was difficult to explain the difference between diploid and triploid samples. The NCBI database was used for gene information annotation; the details are shown in Table 5.

\subsection{RT-qPCR validation}

Genes related to growth which up-regulated in the triploid $P$. tomentosa compared to diploid $P$. tomentosa, as candidate markers for plant breeders in the future, were selected for RT-qPCR validation. There was no peak in the dissolution curves of RT-qPCR products of $G H 3, C A$, and $A-A R R$ gene. And the other seven genes showed a single peak curve, indicating that their amplification products did not contain primer dimers or nonspecific amplification products, and each primer PCR reaction was specific. The results of comparison of the transcriptome analysis and the RT-qPCR analysis are shown in Figure 5A. In diploid plants, the expression levels of the $S A U R, F D P, A L D H, A U X 1$ and $A B F$ in the RT-qPCR analysis were significantly higher than those in the transcriptome analysis. In triploid plants, the expression levels of the $A L D H$ and $A U X 1$ in the RT-qPCR analysis were significantly lower than those in the transcriptome analysis, whereas the expression levels of the malate dehydrogenase $(M D H)$ and $C Y C D 3$ in the RT-qPCR analysis were significantly higher than those in the transcriptome analysis. The expression levels of $A U X 1, C Y C D 3$, and $M D H$ in tissue-cultured triploid poplar were higher than those of tissue-cultured diploid samples, which were consistent with the changes of TMM values calculated by transcriptome. Among them, the expression levels of the $A U X 1$ gene in triploid samples were significantly higher than those in diploid samples (about 6.88 times, logFC value). However, the expression of the $A B F$ gene in diploid samples was higher than that of triploid samples, which was not in accordance with the TMM values. In further experiments, the expression levels of $M D H$ and $C Y C D 3$ in tissue-cultured and greenhouse planted triploid poplar were significantly higher than those of tissue-cultured and greenhouse planted diploid samples. And the expression levels of $M D H$ and $C Y C D 3$ increased with the age gradually (Figure 5, B and C). 
255

256

257

258

259

260

261

262

263

264

265

266

267

268

269

270

271

272

273

274

275

276

277

278

279

280

\section{Discussion}

The transcriptome analysis of the new rooting stem segments of diploid and triploid P. tomentosa showed that most of the significantly different genes were concentrated in plant-pathogen interaction, phenylpropane biosynthesis pathway, and MAPK signalling pathway-plant. Under the condition of comprehensive screening of the GO function enrichment and KEGG function analysis of transcriptome data, it is difficult to determine the expression of specific genes when the genes associated with plant growth appear up-regulated and downregulated. Huang et al (1990) shown there to be larger branches, leaves and fruits in the triploid variety of pear when compared to the diploid variety. And the production of tetraploid radish is $20 \%$ higher than that of ordinary diploids (Liu et al., 2003). Zhu et al. (1995) reported that allotriploidy of $P$. tomentosa had greater values than diploidy under the same growth conditions in tree height, diameter at breast height, and single plant volume at the age of eight years.

It is interesting that although the transcriptome of the diploidy and triploidy of $P$. tomentos $a$ was analysed here, according to the annotations of the specific species distribution chart, only $3.26 \%$ was annotated by $P$. tomentosa. This may partly be due to the fact that the triploid materials used in this study were obtained by the hybridised $P$. bolleana, and some of the mRNAs did not belong in P. tomentosa. Of course, it may also partly be due to the fact that the plant stems were taken from annual plants in this study, which is different to previous studies on $P$. tomentosa. Previous studies on the transcriptome analysis of $P$. tomentosa were mostly based on aseptic seedlings, root one-month-old stem and leaf sample materials (An et al., 2011; Wang et al., 2018), and the expression of mRNA was organ-specific (Ohtsuki et al., 2005).

The phytohormone signal transduction pathway controls plant cell division, cell elongation, cell enlargement, and stem elongation, which is closely related to plant growth and development (Guo et al., 2020). Compared with previous data of transcriptome analysis on phytohormone signal transduction, we selected $A U X 1$, GH3, $A-A R R, C Y C D 3, A B F$ and five other genes for the RT-qPCR validation. Huge differences were found between the expression levels of the selected genes in the RT-qPCR analysis and those of the transcriptome analysis, and we inferred that it might be due to the different growth stages of the experiment's materials. Photosynthesis is an important metabolic process in plants, and its strength has an important effect on plant 
281

282

283

284

285

286

287

288

289

290

291

292

293

294

295

296

297

298

299

300

301

302

303

304

305

306

307

growth, development, and stress resistance. Li and Zhang (2006) found that the lower leaves of the fast-growing triploid $P$. tomentosa clones could maintain a higher photosynthetic rate when measuring the leaf net photosynthetic rate of diploid and triploid $P$. tomentosa. Photosynthesis includes a series of complex reactions in which carbon fixation is a central link in the regulation of photosynthesis (Feng et al., 2006). We compared the data of carbon fixation pathways in previous photosynthetic organism kiwifruit (Li et al., 2019b) and selected the up-regulated malate dehydrogenase $(M D H)$ for the RT-qPCR validation, and the expression levels of $M D H$ gene were up-regulated in triploid $P$. tomentosa plants, compared to the diploid ones.

With the possible exception of the stomatal dimension, the response to polyploidy can be very variable and complex. It has been proved in oilseed rape (Bancroft et al., 2011), sugarcane (Manners and Casu, 2011), cotton (Rambani et al., 2014), wheat (Leach et al., 2014), kiwifruit (Li et al., 2019b), rice (Shenton et al., 2020) and numerous studies in Arabidopsis species, some of which specifically consider triploidy (Fort et al., 2016; 2017; Pacey et al., 2019). Related to the phenomenon, the gene expression levels were not upregulated in any polyploid plant, and over-, under- or mixed-expression of genes were found in the polyploid plant (Osborn et al., 2003; Gutierrez-Gonzalez and Garvin, 2017; Li et al., 2019b). Some genes in polyploid plants were upregulated while others were downregulated compared to diploid plants, which was also found in this study. It illustrated that the allopolyploidy - in particular in P. tomentosa - also alter the gene expression profile and levels as well as those in autopolyploid plants, compared to their diploid relatives. In this study, the expression levels that related to the growth genes such as $M D H$ and $C Y C D 3$ in triploid P. tomentosa were higher than those of diploid P. tomentosa.

$M D H$ is mainly involved in the metabolism of plant photosynthesis (Sawada et al., 2002). The main function of the protein encoded by the $M D H$ gene is to control the carbon dioxide levels during photosynthesis (Sawada et al., 2002). Higher expression levels of the $M D H$ gene was proved to be related to higher rates of photosynthesis (Kandoi et al., 2018), which in turn contributes to higher timber yield. CYCLIN D3 (CYCD3) is a cell-cycle gene, and overexpression of CYCLIN D3;1 (CYCD3;1) in transgenic plants can increase mitotic cycles and reduce endocycles (Menges et al., 2006). CYCD3 was found to regulate cambial cell proliferation and secondary growth, and the protein encoded by the $C Y C D 3$ gene is required for normal vascular development in Arabidopsis (Collins et al., 2015). Previous studies have indicated a relationship between faster growth and the increased expression of the CYCD3 gene. Hence, the upregulation of $M D H$ and $C Y C D 3$ in the triploids is biologically 
308

310

311

312

313

314

315

316

317

318

320

321

322

323

324

325

326

327

meaningful.

There were many DEGs between the diploid and triploid poplar plants that were enriched for a plantpathogen interaction pathway, stress resistance and several growth-related transcripts too. Genes in the plantpathogen interaction pathway are known to be diverse and large in plants and are known to be involved in reproduction isolation across Arabidopsis and Poplars too (Liao et al., 2014; Qian et al., 2018). In this study, one differential gene of the developmental process involved in reproduction was also found in the plant-pathogen interaction pathway. Further, the enrichment of differential expression transcripts in this category could provide useful information to tree breeders who intend to generate heterotic F1s. The pathway enrichment approach also shows several other interesting candidates that would be worth elaborating on in the future relating to studies demonstrating higher stress resistance in the triploid poplar.

\section{Conclusion}

A total of 32,661 DEGs were identified in triploid and diploid Chinese white poplar, of which 15,690 were upregulated and 16,971 were down-regulated in triploidy compared to diploidy. Through the comprehensive analysis of GO functional enrichment analysis and the pathway functional annotation of transcriptome data of diploid and triploid P. tomentosa, no significantly enriched entries and pathways related to growth were found. Compared to diploidy, the growth-related genes were found to be up-regulated and down-regulated in the natural diploid and triploid P. tomentosa trees. Although the expression levels of genes were unstable in the different environments and different growth stages, the expression levels of $M D H$ and $C Y C D 3$ in triploid $P$. tomentosa were higher than those of diploid $P$. tomentosa in young tree tissue, which was consistent with the values calculated using the transcriptome data.

\section{Availability of data and material}

All data generated or analyzed during this study are included in this published article. RNA-Seq data were presented at the Genome Sequence Archive of the Beijing Institute of Genomics (BIG) Data Center (accession number PRJCA002269, https://bigd.big.ac.cn/search?dbId=biosample\&q=PRJCA002269). 
332

333

334

335

\section{Acknowledgments}

The manuscript was proofread by Proofed Inc.(UK).

\section{References}

An XM, Wang DM, Wang ZL, Li B, Bo WH, Cao GL, Zhang ZY. Isolation of a LEAFY homolog from Populus tomentosa: expression of PtLFY in P. tomentosa floral buds and PtLFY-IR-mediated gene silencing in tobacco (Nicotiana tabacum). Plant Cell Reports, 2011, 30(1):89-100. doi: 10.1007/s00299-010-0947-0.

Anders S, Huber W. Differential expression analysis for sequence count data. Genome Biology, 2010,11 : R106.

Bancroft I, Morgan C, Fraser F, Higgins J, Wells R, Clissold L, Baker D, Long Y, Meng J, Wang X, Liu S, Trick M. Dissecting the genome of the polyploid crop oilseed rape by transcriptome sequencing. Nature Biotechnology, 2011, 29(8):762-6. doi: 10.1038/nbt.1926.

Bolger AM, Lohse M, Usadel B. Trimmomatic: a flexible trimmer for Illumina sequence data. Bioinformatics, 2014, 30(15):2114-20. doi: 10.1093/bioinformatics/btu170.

Buchfink B, Xie C, Huson DH. Fast and sensitive protein alignment using DIAMOND. Nature Methods, 2015, 12: 59-60.

Burger T. Gentle introduction to the statistical foundations of false discovery rate in quantitative proteomics. Journal of Proteome Research, 2018, 17(1):12-22. doi: 10.1021/acs.jproteome.7b00170.

Chen TY, Wang B, Wu YY, Wen JL, Liu CF, Yuan TQ, Sun RC. Structural variations of lignin macromolecule from different growth years of triploid of Populus tomentosa Carr. International Journal of Biological Macromolecules, 2017, 101:747-757. doi: 10.1016/j.ijbiomac.2017.03.146.

Chen Y, Chen Y, Shi C, Huang Z, Zhang Y, Li S, Li Y, Ye J, Yu C, Li Z, Zhang X, Wang J, Yang H, Fang L, Chen Q. SOAPnuke: a MapReduce acceleration-supported software for integrated quality control and 
354

355

preprocessing of high-throughput sequencing data. Gigascience, 2018,7(1):1-6. doi: 10.1093/gigascience/gix120.

Ci D, Tian M, Song Y, Du Q, Quan M, Xuan A, Yu J, Yuan Z, Zhang D. Indole-3-acetic acid has long-term effects on long non-coding RNA gene methylation and growth in Populus tomentosa. Molecular Genetics and Genomics, 2019, 294(6):1511-1525. doi: 10.1007/s00438-019-01593-5.

Collins C, Maruthi NM, Jahn CE. CYCD3 D-type cyclins regulate cambial cell proliferation and secondary growth in Arabidopsis. Journal of Experimental Botany, 2015, 66(15):4595-606. doi: 10.1093/jxb/erv218.

Evans M, Hastings N, Peacock B. Statistical Distributions, New York: Wiley-Interscience, Third edition, 2000.

Fan B, Li X, Zhang J, Chen W, Dong H. Decomposition of triploid populus tomentosa fine root and Lolium multiflorum grass root in a composite ecosystem and their nutrient dynamics. Ying Yong Sheng Tai Xue Bao, 2005, 16(11):2030-4. in Chinese.

Feng X, Jia Y, Zhu R, Chen K, Chen Y. Characterization and analysis of the transcriptome in Gymnocypris selincuoensis on the Qinghai-Tibetan Plateau using single-molecule long-read sequencing and RNAseq, DNA Research, 2019, 26(4): 353-363. https://doi.org/10.1093/dnares/dsz014.

Feng Y, Chen X, Shi D, Wang Q. Expression of rice cytoplasmic FBA gene in Anabaena 7120 and its regulation on photosynthesis. Plant Research, 2006 (06): 691-698. in Chinese

Fort A, Ryder P, McKeown PC, Wijnen C, Aarts MG, Sulpice R, Spillane C. Disaggregating polyploidy, parental genome dosage and hybridity contributions to heterosis in Arabidopsis thaliana. New Phytologist, 2016, 209(2):590-9. doi: 10.1111/nph.13650. Epub 2015 Sep 23.

Fort A, Tuteja R, Braud M, McKeown PC, Spillane C. Parental-genome dosage effects on the transcriptome of F1 hybrid triploid embryos of Arabidopsis thaliana. Plant Journal, 2017, 92(6):10441058. doi: 10.1111/tpj.13740. Epub 2017 Nov 28. 
376 Guo J, Lu C, Zhao F, Gao S, Wang B. Improved reproductive growth of euhalophyte Suaeda salsa under

377 salinity is correlated with altered phytohormone biosynthesis and signal transduction. Functional Plant Biology, 2020. doi: 10.1071/FP19215.

Gutierrez-Gonzalez JJ, Garvin DF. De Novo Transcriptome Assembly in Polyploid Species. Methods in Molecular Biology, 2017, 1536: 209-221. doi: 10.1007/978-1-4939-6682-0_15.

Hao S, Zhao T, Xia X, Yin W. Genome-wide comparison of two poplar genotypes with different growth rates. Plant Molecular Biology, 2011;76(6):575-591. doi:10.1007/s11103-011-9790-0.

Harfouche A, Meilan R, Kirst M, Morgante M, Boerjan W, Sabatti M, Scarascia Mugnozza G. Accelerating the domestication of forest trees in a changing world. Trends in Plant Science, 2012, 17(2): 64-72. doi: 10.1016/j.tplants.2011.11.005.

Hu L, Lu H, Liu Q, Chen X, Jiang X. Overexpression of mtlD gene in transgenic Populus tomentosa improves salt tolerance through accumulation of mannitol. Tree Physiology, 2005, 25(10):1273-81.

Huang L, Li S, Cong P. Comparison of polyploid and diploid characters of pear. Chinese Fruit trees, 1990 (03): 30-31+20. in Chinese

Jaikishan I, Rajendrakumar P, Hariprasanna K, Balakrishna D, Bhat BV, Tonapi VA. Identification of differentially expressed transcripts at critical developmental stages in sorghum [Sorghum bicolor (L.) Moench] in relation to grain yield heterosis. 3 Biotech. 2019;9(6):239. doi:10.1007/s13205-019-1777-6.

Kandoi D, Mohanty S, Tripathy BC. Overexpression of plastidic maize NADP-malate dehydrogenase (ZmNADP-MDH) in Arabidopsis thaliana confers tolerance to salt stress. Protoplasma, 2018, 255(2):547563. doi: 10.1007/s00709-017-1168-y.

Lalitha S. Primer premier 5. Biotech Software \& Internet Report, 2000, 1: 270-272.

Leach LJ, Belfield EJ, Jiang C, Brown C, Mithani A, Harberd NP. Patterns of homoeologous gene expression shown by RNA sequencing in hexaploid bread wheat. BMC Genomics. 2014, 15:276. doi: 10.1186/14712164-15-276. 
400

401

402

403

404

405

406

407

408

409

410

411

412

Li B, Dewey CN. RSEM: accurate transcript quantification from RNA-Seqdata with or without a reference genome. BMC Bioinformatics, 2011, 12:323. doi: 10.1186/1471-2105-12-323.

Li J, Gao K, Lei B, Zhou J, Guo T, An X. Altered sucrose metabolism and plant growth in transgenic Populus tomentosa with altered sucrose synthase PtSS3.Transgenic Research, 2019a, doi:10.1007/s11248-01900184-9.

Li J, Zhang Z. Study on photosynthetic characteristics of triploid Populus tomentosa clones. Journal of Beijing Forestry University, 2000 (06): 12-15. in Chinese

Li S, Liu X, Liu H, Zhang X, Ye Q, Zhang H. Induction, identification and genetics analysis of tetraploid Actinidia chinensis. Royal Society Open Science, 2019b, 6: 191052.

Liao W, Ji L, Wang J, Chen Z, Ye M, Ma H, An X. Identification of glutathione S-transferase genes responding to pathogen infestation in Populus tomentosa. Functional and Integrative Genomics. 2014,14(3):517-529. doi:10.1007/s10142-014-0379-y.

Lin YJ, Chen H, Li Q, Li W, Wang JP, Shi R, Tunlaya-Anukit S, Shuai P, Wang Z, Ma H, Li H, Sun YH, Sederoff RR, Chiang VL. Reciprocal cross-regulation of $V N D$ and $S N D$ multigene $T F$ families for wood formation in Populus trichocarpa. Proceedings of the National Academy of Sciences of the United States of America, 2017, 114(45):E9722-E9729. doi: 10.1073/pnas.1714422114.

Liu B, Sun G. Transcriptome and miRNAs analyses enhance our understanding of the evolutionary advantages of polyploidy. Critical Reviews in Biotechnology, 2019, 39(2):173-180. doi: $10.1080 / 07388551.2018 .1524824$.

Liu W, Wang M, Yan Z. Advances in polyploid breeding of vegetable crops. Changjiang vegetables, 2003 (01): 29-33. in Chinese

Liu XZ, Liu XP, Zhang ZM, Sang M, Sun XD, He CZ, Xin PY \& Zhang HY. Functional analysis of the FZF1 genes of Saccharomyces uvarum. Frontiers in Microbiology, 2018, 9: 96. 
423 Manners, JM, Casu, RE (2011) Transcriptome analysis and functional genomics of sugarcane. Trop Plant $424 \quad$ Biology, 4: 9-21.

425 Maza E. In Papyro comparison of TMM (edgeR), RLE (DESeq2), and MRN normalization methods for a 426 simpletwo-conditions-without-replicates RNA-Seq experimental design. Frontiers in Genetics, 2016, 7: 164. doi: 10.3389/fgene.2016.00164.

428

429

430

431

432

Menges M, Samland AK, Planchais S, Murray JA. The D-type cyclin CYCD3;1 is limiting for the G1-to-Sphase transition in Arabidopsis. Plant Cell. 2006,18(4):893-906. doi:10.1105/tpc.105.039636.

Ohtsuki T, Otsuki M, Murakami Y, Maekawa T, Yamamoto T, Akasaka K, Takeuchi S, Takahashi S. Organspecific and age-dependent expression of insulin-like growth factor-I (IGF-I) mRNA variants: IGF-IA and IB mRNAs in the mouse. Zoological Science, 2005, 22(9):1011-21. doi: 10.2108/zsj.22.1011.

Osborn TC, Pires JC, Birchler JA, Auger DL, Chen ZJ, Lee HS, Comai L, Madlung A, Doerge RW, Colot V, Martienssen RA.. Understanding mechanisms of novel gene expression in polyploids. Trends in Genetics, 2003, 19:141-147. doi:10.1016/S0168-9525(03)00015-5.

Pacey EK, Maherali H, Husband BC. The influence of experimentally induced polyploidy on the relationships between endopolyploidy and plant function in Arabidopsis thaliana. Ecology Evolution, 2019, 10(1):198-216. doi: 10.1002/ece3.5886.

Qian C, Yan X, Yin H, Fan X, Yin X, Sun P, Li Z, Nevo E, Ma XF. Transcriptomes divergence of Ricotia lunaria between the two micro-climatic divergent slopes at "Evolution Canyon" I, Israel. Frontiers in Genetics, 2018, 9: 506. doi:10.3389/fgene.2018.00506.

Rambani A, Page JT, Udall JA. Polyploidy and the petal transcriptome of Gossypium. BMC Plant Biology, 2014, 14:3. doi: 10.1186/1471-2229-14-3.

Sanseverino W, Roma G, De Simone M, Faino L, Melito S, Stupka E, Frusciante L, Ercolano R M. PRGdb: a bioinformatics platform for plant resistance gene analysis. Nucleic Acids Research, 2010, 38(Database issue):D814-D821. doi:10.1093/nar/gkp978. 
447 Sattler MC, Carvalho CR, Clarindo WR. The polyploidy and its key role in plant breeding. Planta. 2016, 243(2):281-96. doi: 10.1007/s00425-015-2450-X.

Sawada S, Sakamoto T, Sato M, Kasai M, Usuda H. Photosynthesis with single-rooted Amaranthus leaves. II. Regulation of ribuelose-1,5-bisphosphate carboxylase, phosphoenolpyruvate carboxylase, NAD-malic enzyme and NAD-malate dehydrogenase and coordination between PCR and C4 photosynthetic metabolism in response to changes in the source-sink balance. Plant and Cell Physiology, 2002, 43(11):1293-301. doi: 10.1093/pcp/pcf153.

Sen S, Dehury B, Sahu J, Rathi S, Yadav RNS. Mining and comparative survey of EST-SSR markers among members of Euphorbiaceae family. Molecular Biology Reports, 2018, 45(4):453-468. doi: 10.1007/s11033018-4181-0.

Shenton M, Kobayashi M, Terashima S, Ohyanagi H, Copetti D, Hernández-Hernández T, Zhang J, Ohmido N, Fujita M, Toyoda A, Ikawa H, Fujiyama A, Furuumi H, Miyabayashi T, Kubo T, Kudrna D, Wing R, Yano K, Nonomura KI, Sato Y, Kurata N. Evolution and diversity of the wild rice Oryza officinalis complex, across continents genome types, and ploidy levels.Genome Biology Evolution, 2020 Mar 3. pii: evaa037. doi: 10.1093/gbe/evaa037.

Soltis DE, Soltis PS, Tate JA. Advances in the study of polyploidy since Plant speciation. New Phytolist, 2004, 161:173-191. doi:10.1046/j.1469-8137.2003.00948.x.

Sun P, Jia H, Zhang Y, Li J, Lu M, Hu J. Deciphering genetic architecture of adventitious root and related shoot traits in Populus using QTL mapping and RNA-Seq data. International Journal of Molecular Sciences, 2019, 20(24):6114. doi: 10.3390/ijms20246114.

Tuskan GA, Difazio S, Jansson S, Bohlmann J, Grigoriev I, Hellsten U, Putnam N, Ralph S, Rombauts S, Salamov A, Schein J, Sterck L, Aerts A, Bhalerao RR, Bhalerao RP, Blaudez D, Boerjan W, Brun A, Brunner A, Busov V, Campbell M, Carlson J, Chalot M, Chapman J, Chen GL, Cooper D, Coutinho PM, Couturier J, Covert S, Cronk Q, Cunningham R, Davis J, Degroeve S, Déjardin A, Depamphilis C, Detter J, Dirks B, Dubchak I, Duplessis S, Ehlting J, Ellis B, Gendler K, Goodstein D, Gribskov M, Grimwood J, 
472
Groover A, Gunter L, Hamberger B, Heinze B, Helariutta Y, Henrissat B, Holligan D, Holt R, Huang W, Islam-Faridi N, Jones S, Jones-Rhoades M, Jorgensen R, Joshi C, Kangasjärvi J, Karlsson J, Kelleher C, Kirkpatrick R, Kirst M, Kohler A, Kalluri U, Larimer F, Leebens-Mack J, Leplé JC, Locascio P, Lou Y, Lucas S, Martin F, Montanini B, Napoli C, Nelson DR, Nelson C, Nieminen K, Nilsson O, Pereda V, Peter G, Philippe R, Pilate G, Poliakov A, Razumovskaya J, Richardson P, Rinaldi C, Ritland K, Rouzé P, Ryaboy D, Schmutz J, Schrader J, Segerman B, Shin H, Siddiqui A, Sterky F, Terry A, Tsai CJ, Uberbacher E, Unneberg P, Vahala J, Wall K, Wessler S, Yang G, Yin T, Douglas C, Marra M, Sandberg G, Van de Peer Y, Rokhsar D. The genome of black cottonwood, Populus trichocarpa (Torr. \& Gray). Science, 2006, $313: 1596-1604$.

Wang $\mathrm{L}, \mathrm{Wu} \mathrm{R}$, Bo W. Transcriptome profiling of PeCRYl transgenic Populus tomentosa. Genes and Genomics. 2018, 40(4):349-359. doi: 10.1007/s13258-017-0631-7.

Ye Q, Liu X, Bian W, Zhang Z, Zhang H. Over-expression of transcription factor ARK1 gene leads to downregulation of lignin synthesis related genes in hybrid poplar '717'. Scientific Reports, 2020, 10: 8549. https://doi.org/10.1038/s41598-020-65328-y.

Zhang Q, Zhang ZY, Lin SZ, Zheng HQ, Lin YZ, An XM, Li Y, Li HX. Characterization of resistance gene analogs with a nucleotide binding site isolated from a triploid white poplar. Plant Biololgy (Stuttg). 2008, 10(3):310-22. doi: 10.1111/j.1438-8677.2008.00029.x.

Zhang Y, Xiao Z, Zhan C, Liu M, Xia W, Wang N. Comprehensive analysis of dynamic gene expression and investigation of the roles of hydrogen peroxide during adventitious rooting in poplar. BMC Plant Biology, 2019, 19(1):99. doi: 10.1186/s12870-019-1700-7.

Zhu Z. Polyploid induction, growth and photosynthetic characteristics of Populus davidiana and Populussimonii $\times$ P.nigra. Master thesis, Northeast Forestry University, Harbin, China, 2010. in Chinese

Zong D, Gan P, Zhou A, Li J, Xie Z, Duan A, He C. Comparative analysis of the complete chloroplast genomes of seven Populus species: Insights into alternative female parents of Populus tomentosa. PLoS One, 2019, 14(6):e0218455. doi: 10.1371/journal.pone.0218455.

Peer] reviewing PDF | (2020:04:48280:2:0:CHECK 31 Aug 2020) 
Figure 1 Length distribution of unigenes.

507

508

Figure 2 Classification of the family of transcription factors.

Figure 3 Scatter plot of log diploid and triploid expression data.

511 Red box: representing upregulated transcripts after FDR; gray box: representing non-DEGs; blue box: representing downregulated transcripts.

514 Figure 4 GO secondary node annotation statistics of differential expression genes.

515 Note: The abscissa was the number of genes and the left side of the ordinate was the GO classification.

517 Figure 5 Comparison of the transcriptome analysis and the RT-qPCR analysis. 
518 A: TDP, transcriptome data of diploid plants; RDP, RT-qPCR data of diploid plants; RTP, RT-qPCR data of 519 triploid plants; TTP, transcriptome data of triploid plants. B,C: DP, Diploid plants; TP, triploid plants. These 520 plants were tissue culture plants and planted in greenhouse. 1, 1 month old; 2, 4 months old; 3, 7 months old; 5214,10 months old; 5, 13 months old. The whiskers are standard deviation bars. ${ }^{* *}$, the difference is very significant 522 (P-value $<0.01$ ). RT-qPCR was performed on 3 diploid and 3 triploid plants, which were driven from the same 523 tree used for transcriptome analysis, normalized with housekeeping gene $E F 1 \alpha$, repeated 3 times. The $2^{(-\Delta \Delta \mathrm{Ct})}$ 524 method was utilized to process the data (Liu et al., 2018). Because the difference of the values in Figure 5A was 525 too big, the y-axis of Figure 5A was changed to a log scale.

526

527 
Figure 1

Figure 1 Length distribution of unigenes.

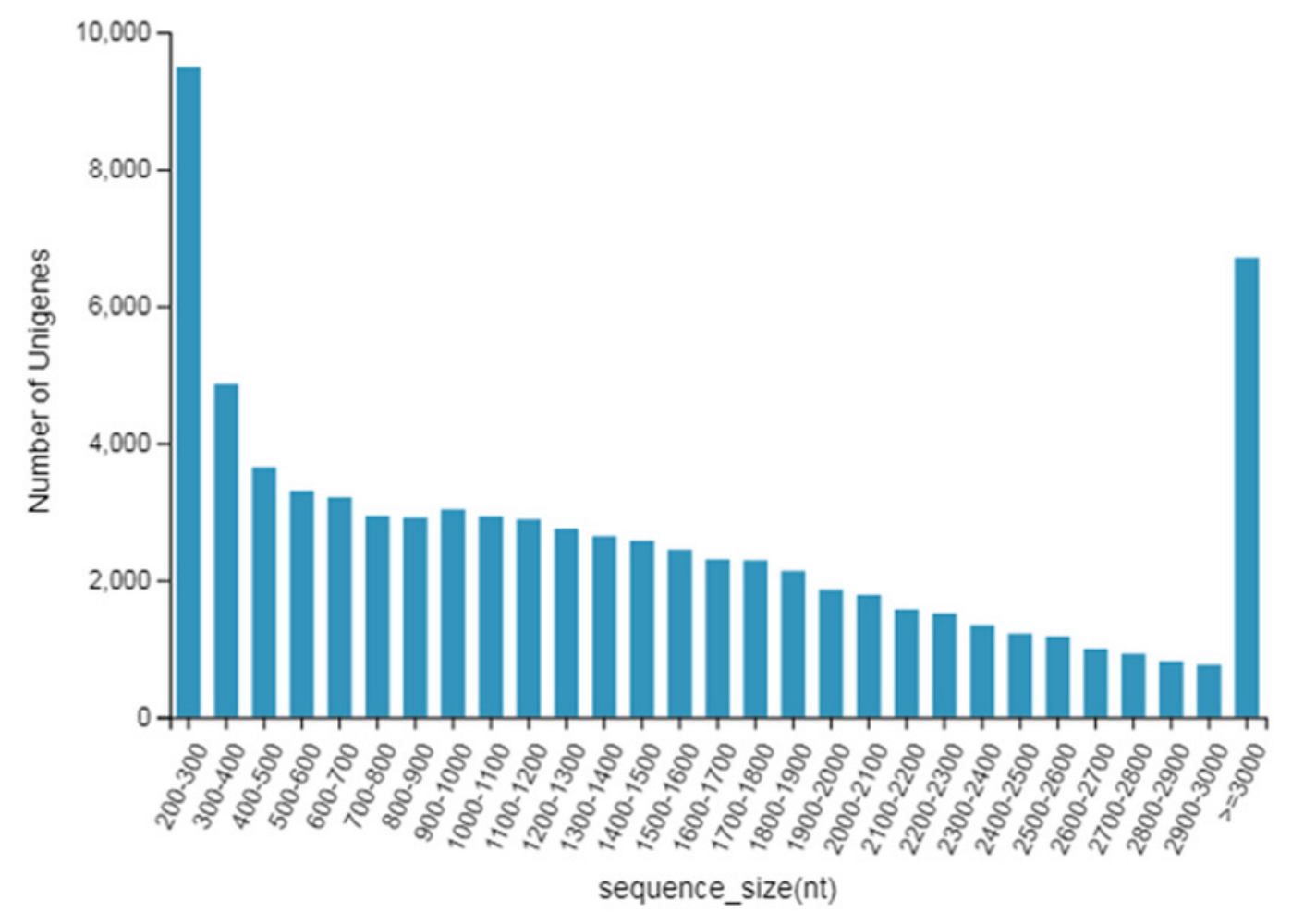

Unigene Number 
Figure 2

Figure 2 Classification of the family of transcription factors. 


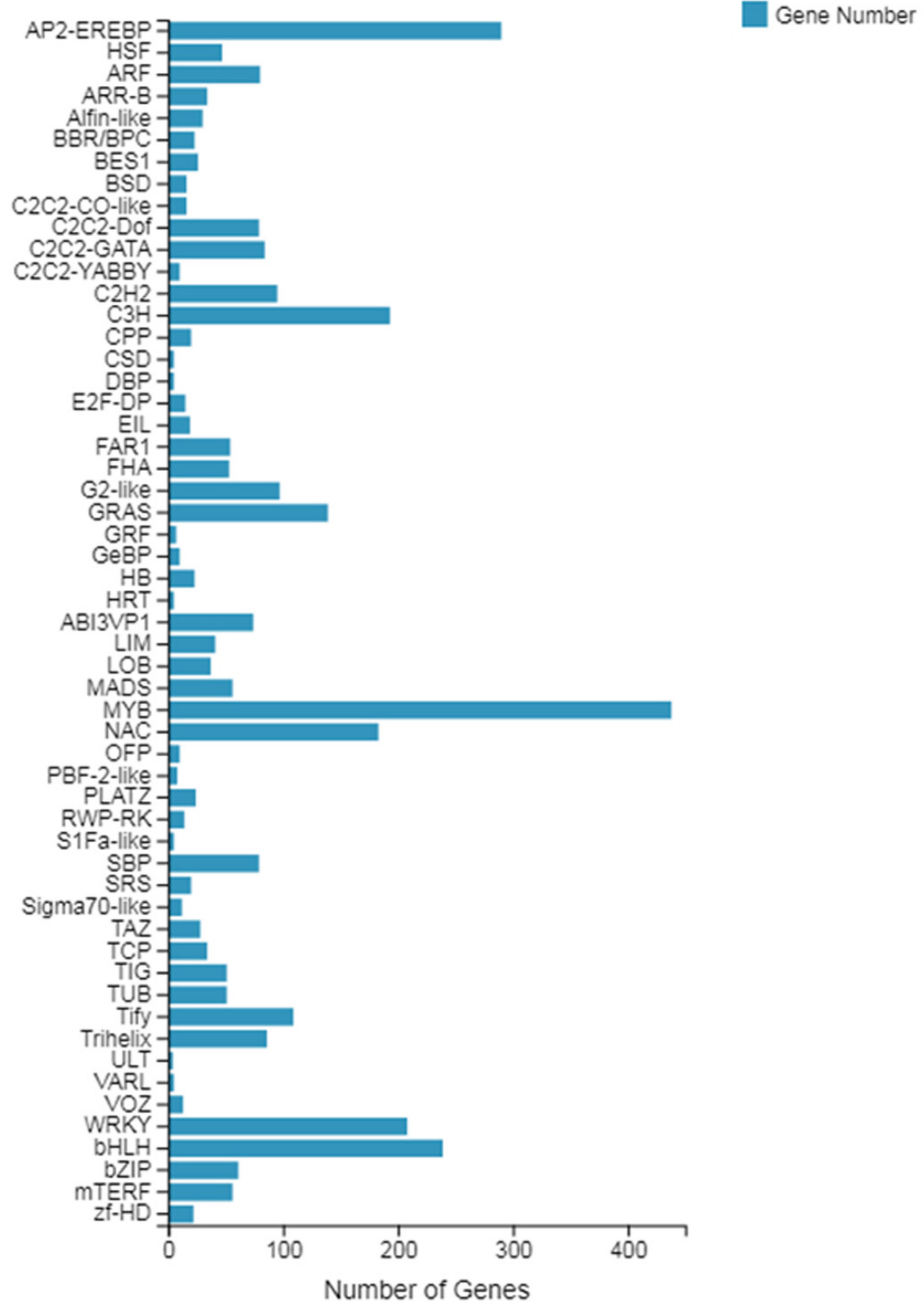


Figure 3

Figure 3 Scatter plot of log diploid and triploid expression data.

Red box: representing upregulated transcripts after FDR; gray box: representing non-DEGs; blue box: representing downregulated transcripts.

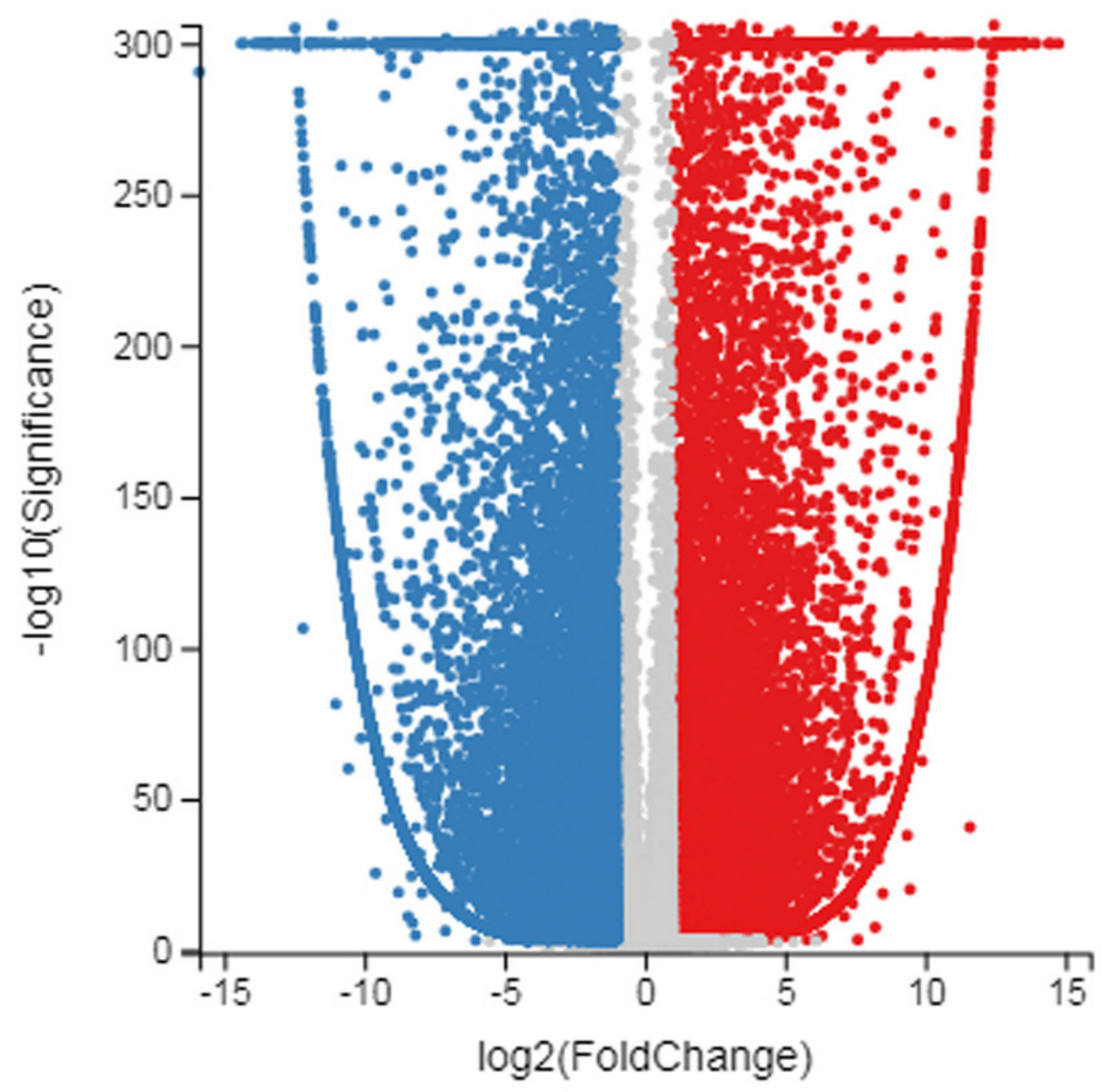




\section{Figure 4}

\section{Figure 4 GO secondary node annotation statistics of differential expression genes.}

Note: The abscissa was the number of genes and the left side of the ordinate was the GO classification.

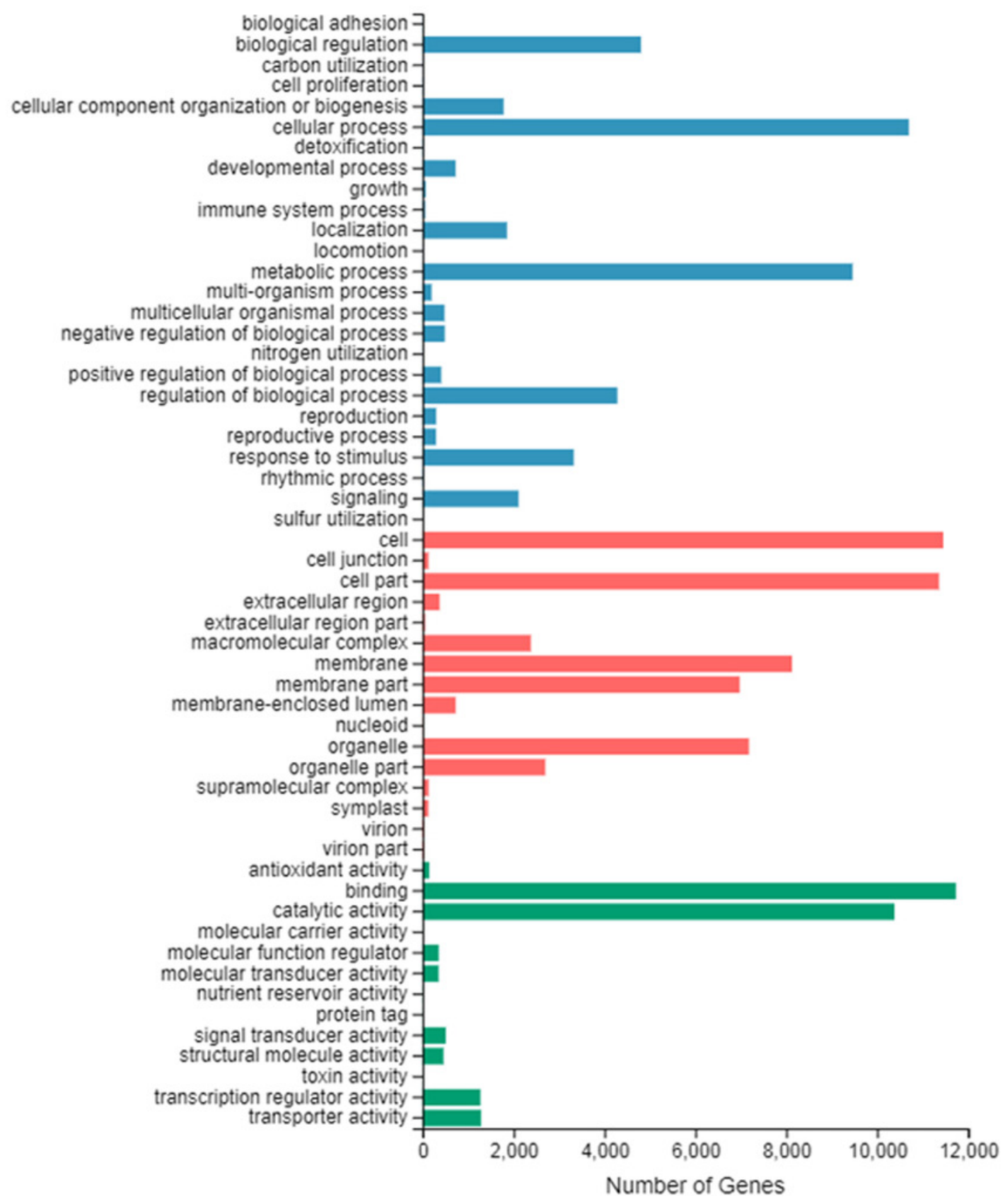




\section{Figure 5}

Figure 5 Comparison of the transcriptome analysis and the RT-qPCR analysis.

A: TDP, transcriptome data of diploid plants; RDP, RT-qPCR data of diploid plants; RTP, RTqPCR data of triploid plants; TTP, transcriptome data of triploid plants. B,C: DP, Diploid plants; TP, triploid plants. These plants were tissue culture plants and planted in greenhouse. 1, 1 month old; 2, 4 months old; 3, 7 months old; 4,10 months old; 5, 13 months old. **, the difference is very significant (P-value $<0.01$ ). RT-qPCR was performed on 3 diploid and 3 triploid plants, which were driven from the same tree used for transcriptome analysis, normalized with housekeeping gene $E F 1 \alpha$, repeated 3 times. The $2^{(-\Delta \Delta C t)}$ method was utilized to process the data (Liu et al., 2018). Because the difference of the values in Figure 5A was too big, the $\mathrm{y}$-axis of Figure 5A was changed to a log scale. 

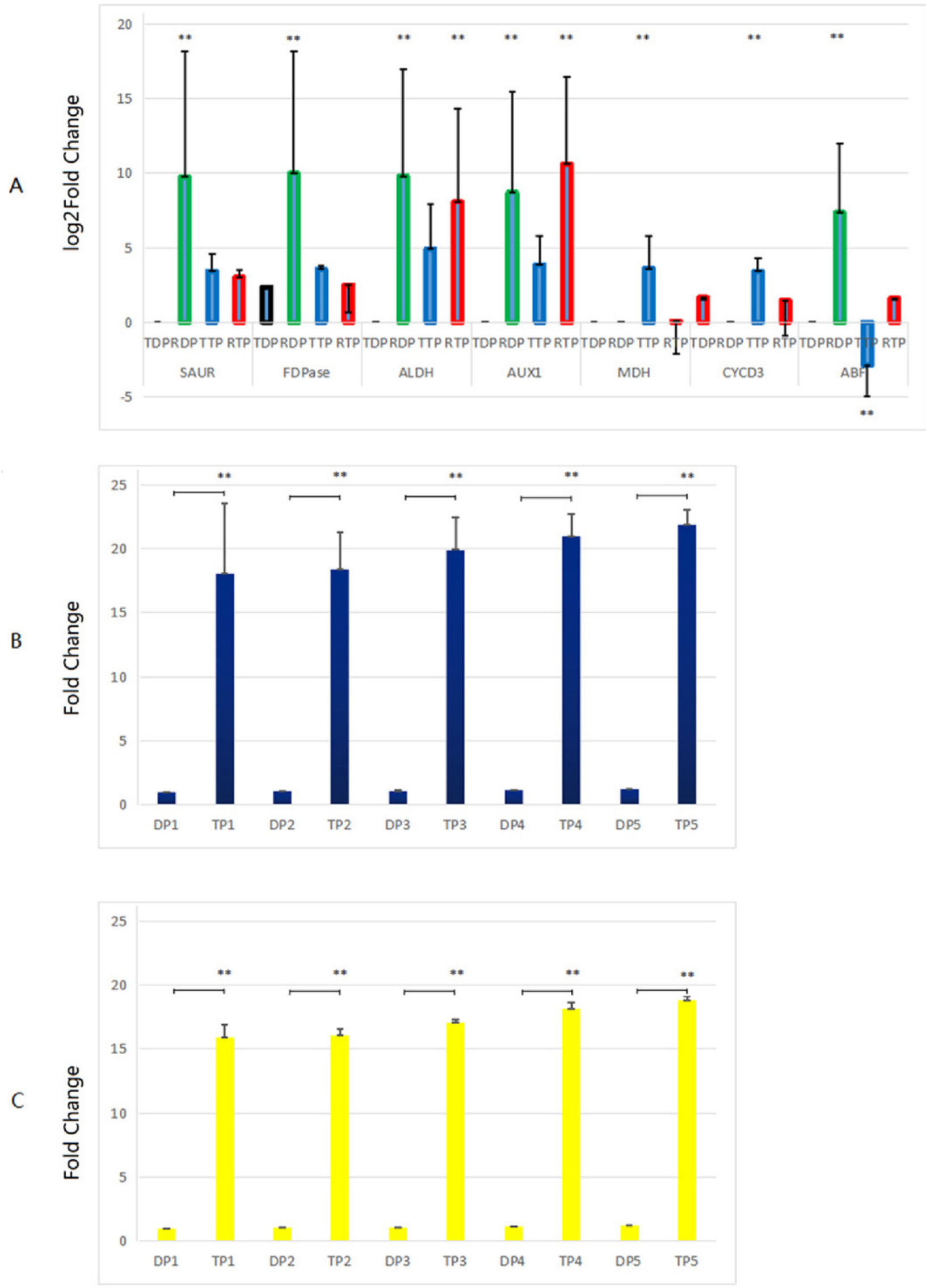


\section{Table 1 (on next page)}

Table.1 The primers used in the RT-qPCR analysis. 
Table.1 The primers used in the RT-qPCR analysis.

\begin{tabular}{|c|c|c|}
\hline Gene Symbol & Upstream and Downstream primer sequence $(5 \rightarrow 3)$ & Product length \\
\hline \multirow{2}{*}{ EF1a } & F: GGCAAGGAGAAGGTACACAT & 204 \\
\hline & R: CAATCACACGCTTGTCAATA & \\
\hline \multirow{2}{*}{$A U X 1$} & F: TGGATCTGTCATTCAACTTATTGCT & 143 \\
\hline & R: AAATACGGTAGTTATGAAAAGAGGGTAT & \\
\hline \multirow{2}{*}{ GH3 } & F: GGACACCGGAAAGAAGAAGGT & 211 \\
\hline & R: CCCTGAAACATCCTAATCAAGCTAC & \\
\hline \multirow{2}{*}{$A-A R R$} & F: AAATCAGGGGGAGCTCTCTT & 100 \\
\hline & R: TTCTACACTTCTGTTGAGCCTGT & \\
\hline \multirow{2}{*}{ CYCD3 } & F: TGCTCTGCTCTCTCTTTGTTCG & 216 \\
\hline & R: CCACTGAAAATCTCACGCCAATC & \\
\hline \multirow{2}{*}{$A B F$} & F: TGGAAAGTGGCAAGTGGGAA & 134 \\
\hline & R: TCAAGACACTGGCAAAGGCA & \\
\hline \multirow{2}{*}{$M D H$} & F: CCGGCTTCATCCACTAGACTC & 153 \\
\hline & R: GAAGGGAAGGGGTGATACCG & \\
\hline \multirow{2}{*}{$C A$} & F: AGAGATTATAATGGCCAGCACCAG & 178 \\
\hline & R: TGGCCCTTTTCCAGTTCCTT & \\
\hline \multirow{2}{*}{$F D P$} & F: ACTCCCAAACACCAAACGAGA & 136 \\
\hline & R: AGCCCACTTGGTATTGGAGC & \\
\hline \multirow{2}{*}{ SAUR } & F: TGCCAAGCAAATTTTCCGCC & 105 \\
\hline & R: ACTGGAACCACAAATCGCTTC & \\
\hline
\end{tabular}


1
$A L D H$

F: TGCTGGTGGACTTGAGGATT

R: ATCAAAGAAATGGAGAATAGGCAGA
168 


\section{Table 2 (on next page)}

Table.2 DEGs belonged to lignin production related transcripts.

Note: a, large categories only includes biological process, cellular component and molecular function; b, subcategories under each large category. 
Table.2 DEGs belonged to lignin production related transcripts.

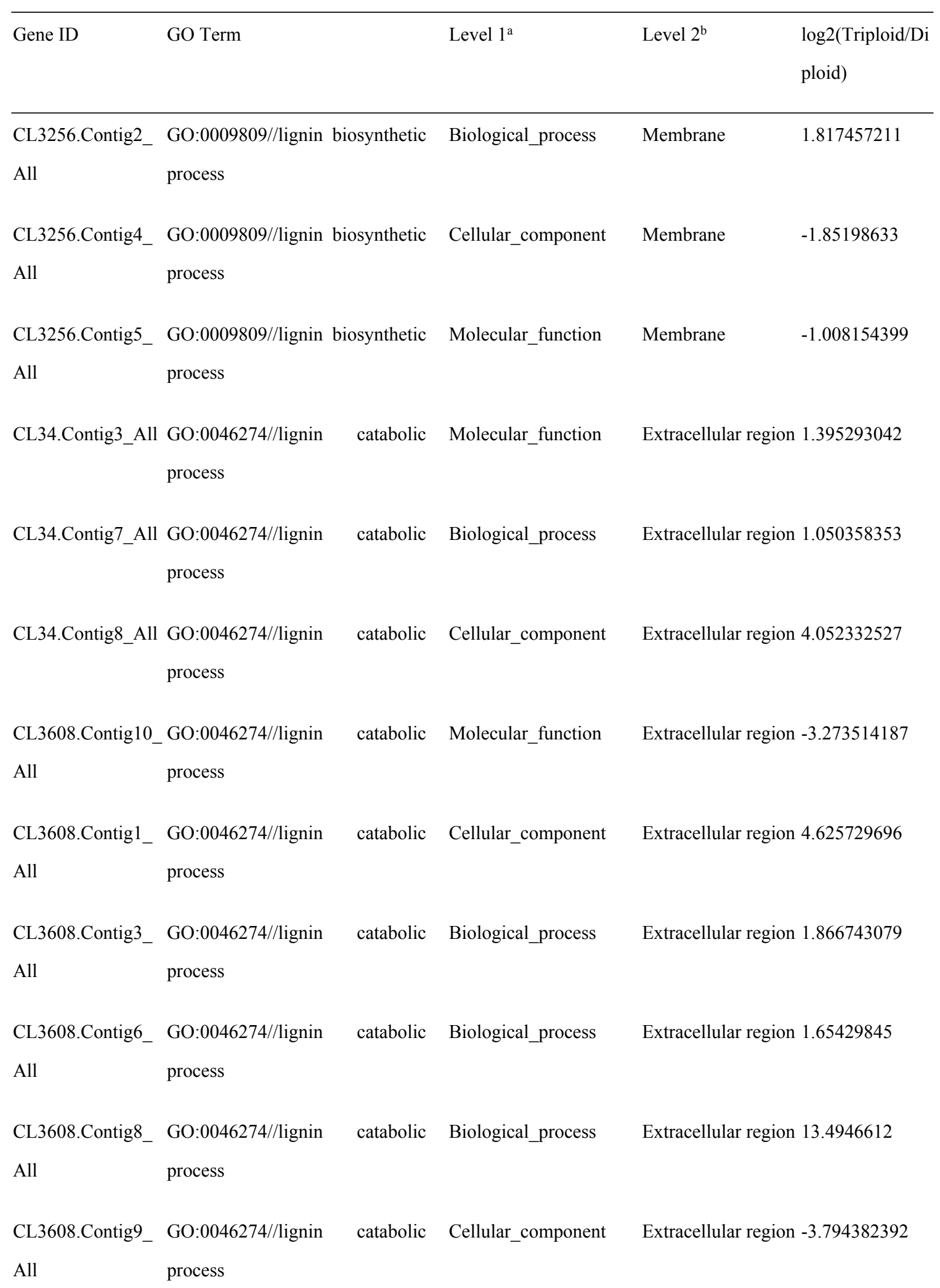




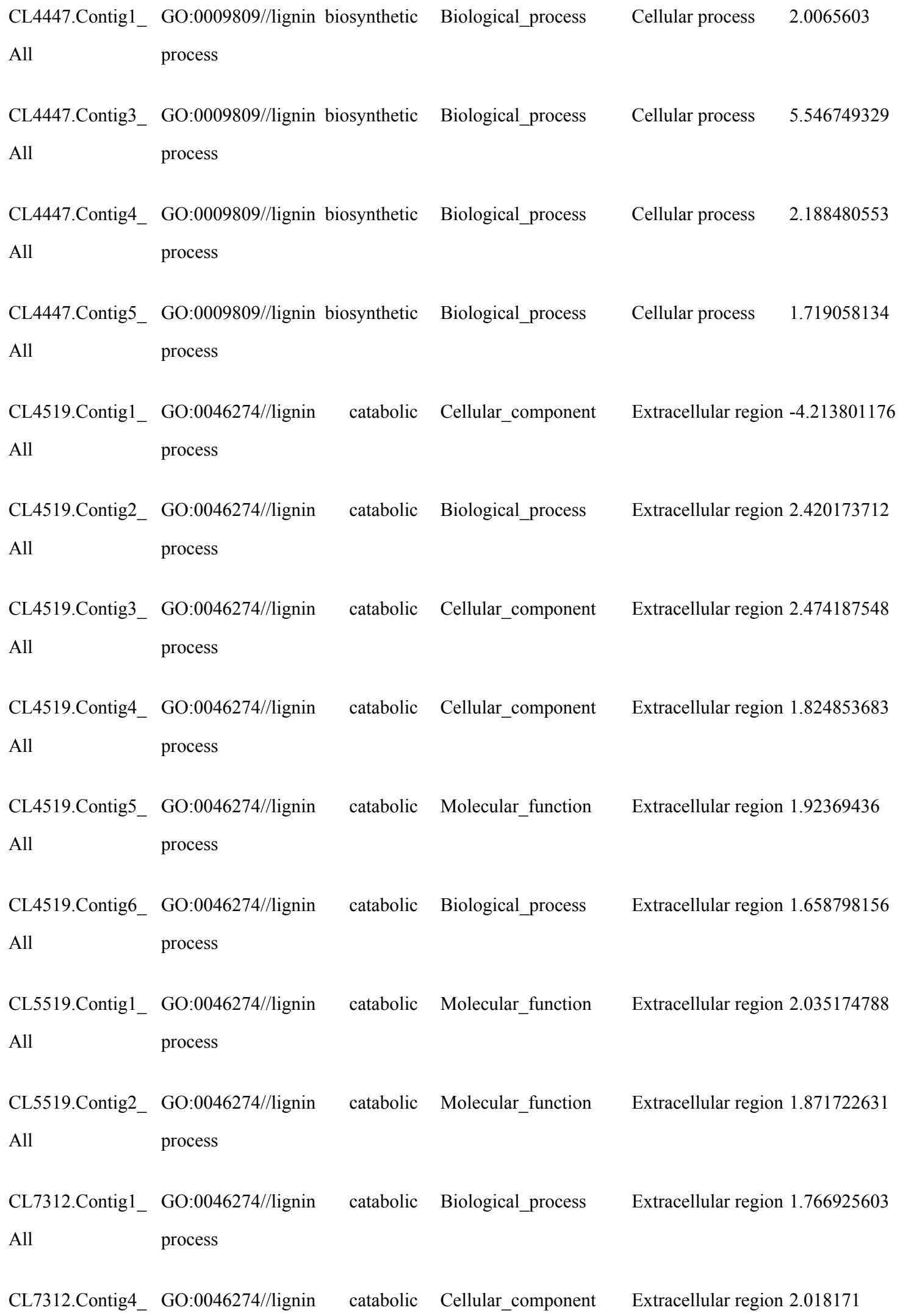




\begin{tabular}{|c|c|c|c|c|c|}
\hline All & process & & & & \\
\hline CL7312.Contig5_ & GO:0046274//lignin & catabolic & Molecular_function & Extracellula & 2.303556773 \\
\hline All & process & & & & \\
\hline CL7312.Contig6_ & GO:0046274//lignin & catabolic & Biological_process & Extracellula & 1.686600197 \\
\hline All & process & & & & \\
\hline CL8534.Contig3_ & GO:0009809//lignin & biosynthetic & Biological_process & Membrane & 1.847328294 \\
\hline All & process & & & & \\
\hline CL914.Contig4_A & GO:0009808//lignin & metabolic & Cellular_component & Membrane & -2.280202421 \\
\hline 1 & process & & & & \\
\hline CL914.Contig5_A & GO:0009808//lignin & metabolic & Molecular_function & Membrane & -5.156601442 \\
\hline 1 & process & & & & \\
\hline CL9567.Contig1_ & GO:0046274//lignin & catabolic & Cellular_component & Extracellula & -2.96038825 \\
\hline All & process & & & & \\
\hline CL9787.Contig1_ & GO:0046274//lignin & catabolic & Cellular_component & Extracellul & 1.036570867 \\
\hline
\end{tabular}




\begin{tabular}{|c|c|c|c|c|}
\hline Unigene24809_Al & $\begin{array}{l}\text { GO:0046274//lignin } \\
\text { process }\end{array}$ & catabolic & Cellular_component & Extracellular region 4.060836332 \\
\hline Unigene314_All & $\begin{array}{l}\text { GO:0046274//lignin } \\
\text { process }\end{array}$ & catabolic & Cellular_component & Extracellular region 2.01007043 \\
\hline Unigene428_All & $\begin{array}{l}\text { GO:0046274//lignin } \\
\text { process }\end{array}$ & catabolic & Cellular_component & Extracellular region 1.572211841 \\
\hline Unigene5164_All & $\begin{array}{l}\text { GO:0009808//lignin } \\
\text { process }\end{array}$ & metabolic & Biological_process & Membraneactivity $\quad-1.626207392$ \\
\hline Unigene8384_All & $\begin{array}{l}\text { GO:0046274//lignin } \\
\text { process }\end{array}$ & catabolic & Biological_process & Extracellular region 1.219895563 \\
\hline
\end{tabular}

3 subcategories under each large category.

4 


\section{Table 3(on next page)}

Table.3 Entries were enriched in GO function.

Note: a, large categories only includes biological process, cellular component and molecular function; b, subcategories under each large category. 
1 Table.3 Entries were enriched in GO function.

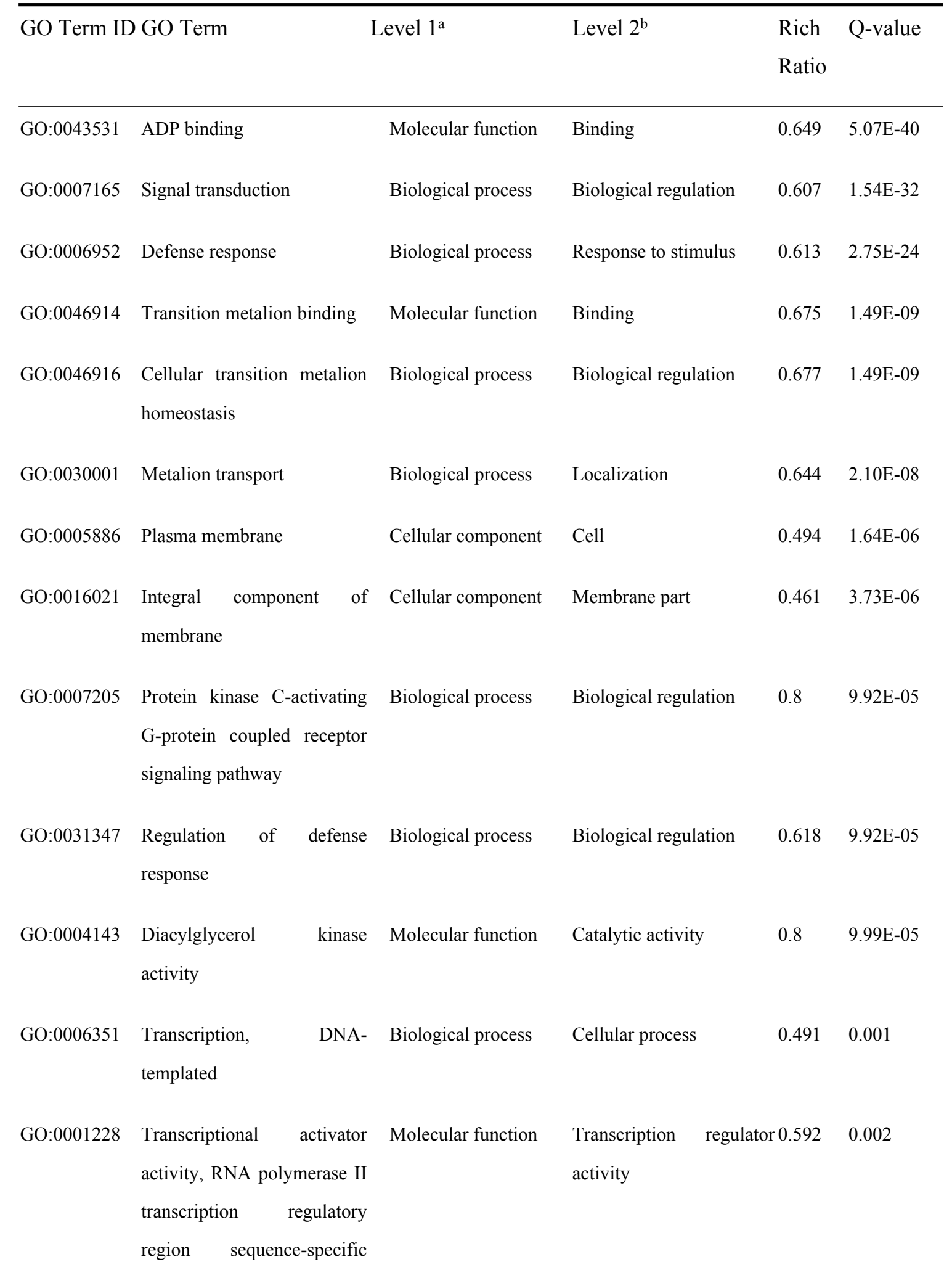


DNA binding

\begin{tabular}{|c|c|c|c|c|c|}
\hline GO:0046658 & $\begin{array}{l}\text { Anchored component of } \\
\text { plasma membrane }\end{array}$ & Cellular component & Cell & 0.565 & 0.002 \\
\hline GO:0009611 & Response to wounding & Biological process & Response to stimulus & 0.613 & 0.002 \\
\hline GO:0048046 & Apoplast & Cellular component & Extracellular region & 0.609 & 0.002 \\
\hline GO:2000022 & $\begin{array}{l}\text { Regulation of jasmonic acid } \\
\text { mediated signaling pathway }\end{array}$ & Biological process & Biological regulation & 0.625 & 0.002 \\
\hline GO:1903507 & $\begin{array}{l}\text { Negative regulation of } \\
\text { nucleic acid-templated } \\
\text { transcription }\end{array}$ & Biological process & Biological regulation & 0.629 & 0.003 \\
\hline GO:0000977 & $\begin{array}{l}\text { RNA polymerase II } \\
\text { regulatory region sequence- } \\
\text { specific DNA binding }\end{array}$ & Molecular function & Binding & 0.570 & 0.003 \\
\hline GO:0003700 & $\begin{array}{l}\text { DNA binding transcription } \\
\text { factor activity }\end{array}$ & Molecular function & $\begin{array}{l}\text { Transcription regu } \\
\text { activity }\end{array}$ & r 0.497 & 0.003 \\
\hline GO:0003839 & $\begin{array}{l}\text { Gamma- } \\
\text { glutamylcyclotransferase } \\
\text { activity }\end{array}$ & Molecular function & Catalytic activity & 0.941 & 0.004 \\
\hline GO:0006979 & Response to oxidative stress & Biological process & Response to stimulus & 0.596 & 0.006 \\
\hline GO:0005576 & Extracellular region & Cellular component & Extracellular region & 0.541 & 0.006 \\
\hline GO:0016298 & Lipase activity & Molecular function & Catalytic activity & 0.698 & 0.006 \\
\hline GO:0016020 & Membrane & Cellular component & Membrane & 0.501 & 0.007 \\
\hline GO:0006629 & Lipid metabolic process & Biological process & Metabolic process & 0.550 & 0.010 \\
\hline GO:0016747 & $\begin{array}{l}\text { Transferase activity, } \\
\text { transferring acyl groups } \\
\text { other than amino-acyl } \\
\text { groups }\end{array}$ & Molecular function & Catalytic activity & 0.578 & 0.012 \\
\hline
\end{tabular}




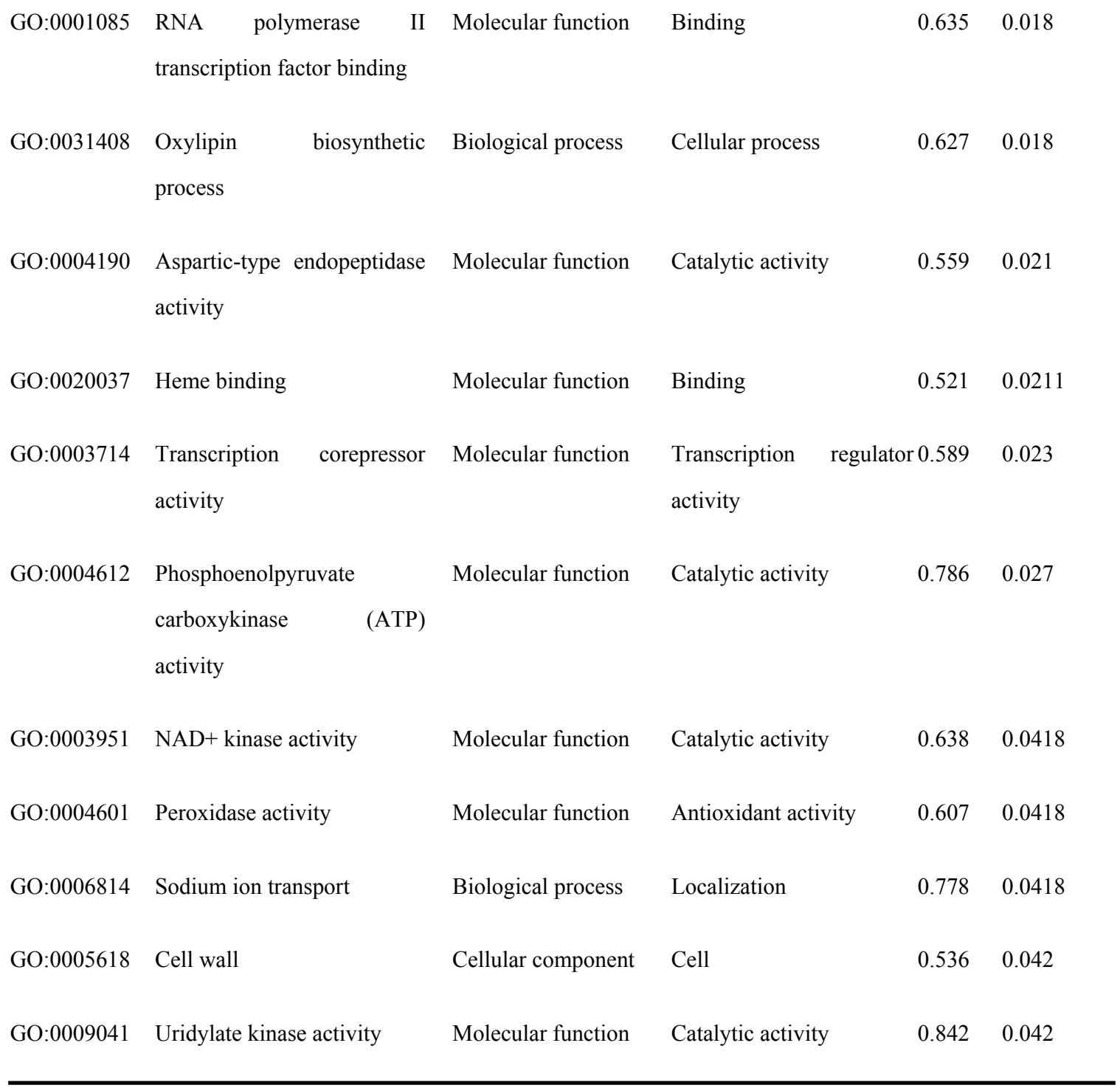

2

4 subcategories under each large category.

5

6

7 


\section{Table 4(on next page)}

Table.4 Differentially expressed genes significantly enriched KEGG pathways.

Note: a, large categories only includes cellular processes, environmental information processing, genetic information processing, metabolism and organismal systems; $b$, subcategories under each large category. 
1 Table.4 Differentially expressed genes significantly enriched KEGG pathways.

\begin{tabular}{|c|c|c|c|c|c|}
\hline $\begin{array}{l}\text { Pathway } \\
\text { ID }\end{array}$ & Pathway Name & Level $1^{\mathrm{a}}$ & Level $2^{\mathrm{b}}$ & $\begin{array}{l}\text { Rich } \\
\text { Ratio }\end{array}$ & $\mathrm{Q}$ value \\
\hline ko04626 & $\begin{array}{l}\text { Plant-pathogen } \\
\text { interaction }\end{array}$ & Organismal Systems & Environmental adaptation & 0.572 & $1.62 \mathrm{E}-20$ \\
\hline ko00940 & $\begin{array}{l}\text { Phenylpropanoid } \\
\text { biosynthesis }\end{array}$ & Metabolism & $\begin{array}{l}\text { Biosynthesis of other secondary } \\
\text { metabolites }\end{array}$ & 0.561 & $1.29 \mathrm{E}-05$ \\
\hline ko04016 & $\begin{array}{l}\text { MAPK signaling } \\
\text { pathway - plant }\end{array}$ & $\begin{array}{l}\text { Environmental Information } \\
\text { Processing }\end{array}$ & Signal transduction & 0.522 & $5.41 \mathrm{E}-05$ \\
\hline ko00053 & $\begin{array}{l}\text { Ascorbate and } \\
\text { aldarate metabolism }\end{array}$ & Metabolism & Carbohydrate metabolism & 0.574 & 0.003 \\
\hline ko00904 & $\begin{array}{l}\text { Diterpenoid } \\
\text { biosynthesis }\end{array}$ & Metabolism & $\begin{array}{l}\text { Metabolism of terpenoids and } \\
\text { polyketides }\end{array}$ & 0.653 & 0.003 \\
\hline ko00965 & $\begin{array}{l}\text { Betalain } \\
\text { biosynthesis }\end{array}$ & Metabolism & $\begin{array}{l}\text { Biosynthesis of other secondary } \\
\text { metabolites }\end{array}$ & 0.694 & 0.005 \\
\hline ko00591 & $\begin{array}{l}\text { Linoleic acid } \\
\text { metabolism }\end{array}$ & Metabolism & Lipid metabolism & 0.604 & 0.007 \\
\hline ko04712 & $\begin{array}{l}\text { Circadian rhythm- } \\
\text { plant }\end{array}$ & Organismal Systems & Environmental adaptation & 0.532 & 0.007 \\
\hline ko00944 & $\begin{array}{l}\text { Flavone and } \\
\text { flavonol } \\
\text { biosynthesis }\end{array}$ & Metabolism & $\begin{array}{l}\text { Biosynthesis of other secondary } \\
\text { metabolites }\end{array}$ & 0.743 & 0.011 \\
\hline ko00052 & $\begin{array}{l}\text { Galactose } \\
\text { metabolism }\end{array}$ & Metabolism & Carbohydrate metabolism & 0.529 & 0.027 \\
\hline ko00561 & $\begin{array}{l}\text { Glycerolipid } \\
\text { metabolism }\end{array}$ & Metabolism & Lipid metabolism & 0.533 & 0.033 \\
\hline
\end{tabular}




\begin{tabular}{|c|c|c|c|c|}
\hline ko00941 & $\begin{array}{l}\text { Flavonoid } \\
\text { biosynthesis }\end{array}$ & Metabolism & $\begin{array}{l}\text { Biosynthesis of other secondary } 0.557 \\
\text { metabolites }\end{array}$ & 0.033 \\
\hline ko00073 & $\begin{array}{l}\text { Cutin, suberine and } \\
\text { wax biosynthesis }\end{array}$ & Metabolism & Lipid metabolism & 0.037 \\
\hline ko00903 & $\begin{array}{l}\text { Limonene and } \\
\text { pinene degradation }\end{array}$ & Metabolism & $\begin{array}{l}\text { Metabolism of terpenoids and } 0.649 \\
\text { polyketides }\end{array}$ & 0.037 \\
\hline ko00900 & $\begin{array}{l}\text { Terpenoid } \\
\text { backbone } \\
\text { biosynthesis }\end{array}$ & Metabolism & $\begin{array}{l}\text { Metabolism of terpenoids and } 0.545 \\
\text { polyketides }\end{array}$ & 0.045 \\
\hline ko00945 & $\begin{array}{l}\text { Stilbenoid, } \\
\text { diarylheptanoid and } \\
\text { gingerol } \\
\text { biosynthesis }\end{array}$ & Metabolism & $\begin{array}{l}\text { Biosynthesis of other secondary } 0.604 \\
\text { metabolites }\end{array}$ & 0.045 \\
\hline
\end{tabular}

3 information processing, metabolism and organismal systems; b, subcategories under each large category. 


\section{Table 5 (on next page)}

Table.5 Information of growth-related differential genes. 
1 Table.5 Information of growth-related differential genes.

\begin{tabular}{|c|c|c|c|c|}
\hline \multirow[t]{4}{*}{ KEGG pathway } & \multirow[b]{2}{*}{ AUX1 } & GIDs & Gene annotation & \multirow{2}{*}{$\begin{array}{l}\text { Gene function } \\
\text { Cell enlargement, plant } \\
\text { growth }\end{array}$} \\
\hline & & $\begin{array}{l}\text { XM_01104 } \\
9129.1\end{array}$ & $\begin{array}{l}\text { Populus euphratica auxin } \\
\text { transporter-like protein } \\
\text { (LOC105141777), transcript variant } \\
\text { X1, mRNA }\end{array}$ & \\
\hline & $\mathrm{GH} 3$ & $\begin{array}{l}\text { XM_01103 } \\
2075.1\end{array}$ & $\begin{array}{l}\text { P. euphratica probable indole-3- } \\
\text { acetic acid-amido synthetase GH3.1 } \\
\text { (LOC105129841), mRNA }\end{array}$ & $\begin{array}{l}\text { Indirect regulation of cell } \\
\text { expansion and plant } \\
\text { growth }\end{array}$ \\
\hline & A-ARR & $\begin{array}{l}\text { XM_01100 } \\
2137.1\end{array}$ & $\begin{array}{l}P . \quad \text { euphratica two-component } \\
\text { response regulator ARR } \\
\text { (LOC105108010), mRNA }\end{array}$ & $\begin{array}{l}\text { Cell division and bud } \\
\text { formation }\end{array}$ \\
\hline Ko04075 & CYCD3 & $\begin{array}{l}\text { XM_01101 } \\
0474.1\end{array}$ & $\begin{array}{l}\text { P. euphratica cyclin-D3-3-like } \\
\text { (LOC105114061), mRNA }\end{array}$ & $\begin{array}{l}\text { Indirect regulation of cell } \\
\text { dvision and cell } \\
\text { elongation }\end{array}$ \\
\hline $\begin{array}{l}\text { Plant hormone } \\
\text { signal } \\
\text { transduction }\end{array}$ & $\mathrm{ABF}$ & $\begin{array}{l}\text { XM_01104 } \\
3006.1\end{array}$ & $\begin{array}{l}\text { P. euphratica ABSCISIC ACID- } \\
\text { INSENSITIVE 5-like protein } 2 \\
\text { (LOC105137304), transcript variant } \\
\text { X2, mRNA }\end{array}$ & $\begin{array}{l}\text { Participation in stress } \\
\text { resistance processes such } \\
\text { as low temperature, high } \\
\text { salt and oxidation stress, } \\
\text { and involvement in plant } \\
\text { growth and development }\end{array}$ \\
\hline $\begin{array}{l}\text { Ko00710 } \\
\text { Carbon fixation } \\
\text { in photosynthetic } \\
\text { organisms }\end{array}$ & $\mathrm{MDH}$ & $\begin{array}{l}\text { XM_01100 } \\
4743.1\end{array}$ & $\begin{array}{l}P . \quad \text { euphratica } \quad \text { oligopeptide } \\
\text { transporter } 4 \text { (LOC105109875), } \\
\text { mRNA }\end{array}$ & $\begin{array}{l}\text { Participation in the TCA } \\
\text { cycle, photosynthesis, C4 } \\
\text { cycle, and other } \\
\text { metabolic pathways to } \\
\text { promote plant growth } \\
\text { and development }\end{array}$ \\
\hline
\end{tabular}

